\title{
Characterization of polychlorinated naphthalenes in stack gas emissions from waste incinerators
}

\author{
Jicheng Hu • Minghui Zheng • Wenbin Liu • \\ Changliang Li • Zhiqiang Nie • Guorui Liu • \\ Bing Zhang $\cdot$ Ke Xiao $\cdot$ Lirong Gao
}

Received: 26 June 2012 / Accepted: 19 September 2012 /Published online: 29 September 2012

(C) Springer-Verlag Berlin Heidelberg 2012

\begin{abstract}
Nine typical waste incinerating plants were investigated for polychlorinated naphthalene $(\mathrm{PCN})$ contents in their stack gas. The incinerators investigated include those used to incinerate municipal solid, aviation, medical, and hazardous wastes including those encountered in cement kilns. PCNs were qualified and quantified by isotope dilution high resolution gas chromatography-high resolution mass spectrometry techniques. An unexpectedly high concentration of PCNs $\left(13,000 \mathrm{ng} \mathrm{Nm}^{-3}\right)$ was found in the stack gas emitted from one waste incinerator. The PCN concentrations ranged from 97.6 to $874 \mathrm{ng} \mathrm{Nm}^{-3}$ in the other waste incinerators. The PCN profiles were dominated by lower chlorinated homologues, with mono- to tetra-CNs being the main homologues present. Furthermore, the relationships between PCNs and other unintentional persistent organic pollutants involving polychlorinated dibenzo- $p$-dioxins and dibenzofurans, polychlorinated biphenyls, hexachlorobenzene, and pentachlorobenzene were examined to ascertain the closeness or otherwise of their formation mechanisms. A good correlation was observed between $\Sigma \mathrm{PCN}$ (tetra- to octa-CN) and $\Sigma$ PCDF (tetra- to octa-CDF) concentrations suggesting that a close relationship may exist between their formation mechanisms. The results would provide an
\end{abstract}

Responsible editor: Gerhard Lammel

Electronic supplementary material The online version of this article (doi:10.1007/s11356-012-1218-0) contains supplementary material, which is available to authorized users.

$\mathrm{J}$. Hu $\cdot$ M. Zheng $(\bowtie) \cdot$ W. Liu $\cdot \mathrm{C} . \mathrm{Li} \cdot \mathrm{Z}$. Nie $\cdot \mathrm{G}$. Liu $\cdot$

B. Zhang $\cdot$ K. Xiao $\cdot$ L. Gao

State Key Laboratory of Environmental Chemistry and

Ecotoxicology, Research Center for Eco-Environmental Sciences,

Chinese Academy of Sciences,

P.O. Box 2871, Beijing 100085, China

e-mail: zhengmh@rcees.ac.cn improved understanding of PCN emissions from waste incinerators.

Keywords Polychlorinated naphthalenes · Waste incinerator $\cdot$ Stack gas emissions $\cdot$ Dioxins $\cdot$ Unintentional POPs $\cdot$ Stockholm Convention

\section{Introduction}

Polychlorinated naphthalenes (PCNs), a family of tworinged aromatic compounds, are ubiquitous environmental pollutants (Domingo 2004; Bidleman et al. 2010). Seventyfive possible congeners exist based on naphthalene substituted with one to eight chlorine atoms. PCNs exhibit dioxinlike toxicities as a result of their structural similarity to dioxins (Falandysz 1998; Olivero-Verbel et al. 2004). They have been used in a variety of industrial applications, such as dye-making; as fungicides in the wood, textile, and paper industries; as plasticizers; and as oil additives (Bidleman et al. 2010). The total global PCN production is estimated to be $10 \%$ of polychlorinated biphenyl (PCB) production or 150,000 $t$ (Falandysz 1998; Helm and Bidleman 2003). The production and use of PCNs have been banned in the USA and Europe since the 1980s (Marti-Cid et al. 2008). However, PCNs can be produced unintentionally by industrial thermal processes such as waste incinerators, secondary nonferrous metallurgical facilities, and coking industries and may eventually be released into the environment (Imagawa and Lee 2001; Oh et al. 2007; Ba et al. 2010; Liu et al. 2010).

Furthermore, the influence of combustion sources on the levels and profiles of PCNs in air has also been reported at an industrialized location in Toronto, Canada (Helm and 
Bidleman 2003). In terms of toxic equivalency (TEQ), PCN levels in human blood have been found to exist in concentrations slightly greater than other dioxin-like compounds (Park et al. 2010). Park et al. (2010) determined PCN, polychlorinated dibenzo- $p$-dioxins (PCDDs), polychlorinated dibenzofurans (PCDFs), and PCB concentrations in the serum of individuals working at municipal solid waste (MSW) incinerators as well as those living in close proximity to these facilities and realized that the PCNs contribution to total TEQ in the serum $(26.8 \%)$ was slightly greater than that of the PCDDs (23.8\%), PCDFs (25.0\%), and PCBs (24.3\%). Thus, PCNs emitted from waste incinerators have attracted increasing attention for their potential impact on the ambient environment and human health.

Some studies have been conducted to understand how PCNs form and several formation mechanisms have been suggested such as chlorination of naphthalene, de novo synthesis from polycyclic aromatic hydrocarbons (PAHs), and chlorophenol condensation (Weber et al. 2001; Oh et al. 2007; Jansson et al. 2008; Liu et al. 2010). To investigate the formation mechanisms, the relationships between PCNs and other incinerator emission compounds, such as naphthalene, PAHs, and PCDD/Fs, were examined. These compounds may be co-formed by similar mechanisms or may serve as reactants to form PCNs. Oh et al. (2007) found that a strong correlation existed between PCNs and PCDFs and adjacent $\mathrm{PCN}$ homologue groups were closely related to one another. They suggested that PCN formation was related to chlorination/dechlorination mechanisms, similar to PCDFs formation. Meanwhile, Weber et al. (2001) suggested that PCNs can be formed via de novo synthesis from PAHs based on results of the de novo experiments. The formation mechanism of PCNs is, however, still unclear and needs further study.

In recent years, a large portion of the literature on the emission of dioxin-like compounds from waste incinerators has focused on PCDD/Fs and PCBs (Behnisch et al. 2002; Shin et al. 2006; Jansson et al. 2009; Ni et al. 2009; Weggiel et al. 2011; Yan et al. 2011). Fewer investigations have been conducted on PCNs, especially regarding their release from stack gas in relation to the types and scales of waste incinerators. In this study, nine different waste incinerating plants were investigated for PCN contents in the stack gas. The incinerators investigated include those used to incinerate MSW, aviation, medical, and hazardous wastes including those encountered in cement kilns. The relationships between PCNs and other unintentional persistent organic pollutants (U-POPs) including PCDD/Fs, PCBs, hexachlorobenzene $(\mathrm{HxCBz})$, and pentachlorobenzene $(\mathrm{PeCBz})$ under the Stockholm Convention were examined to ascertain the similarities or otherwise of their formation mechanisms. The findings of this study would be useful for controlling $\mathrm{PCN}$ emissions from waste incinerators.

\section{Materials and methods}

\section{Sample collection}

A total of 27 stack gas samples were collected from nine different waste incinerators, including those used to incinerate MSW, aviation, medical, and hazardous wastes (detailed information in Table 1). Three stack gas samples from each waste incinerator were collected by an automatic isokinetic sampling system, Isostack Basic (TCR TECORA, Italy) according to European Standard EN-1948: part 1. The sampling point was set downstream of all air pollution control systems (APCSs). Particles in the stack gas were trapped by a microfiber thimble filter $(25 \mathrm{~mm}$ i.d., $90 \mathrm{~mm}$ length, Whatman). Gasses were cooled in a condensing system and then adsorbed in a trap with Amberlite XAD-2 resin (Supleco International Ltd., Varina). The resin was spiked with sampling standards (three surrogate target compounds: ${ }^{13} \mathrm{C}_{12}-1,2,3,7,8-\mathrm{PeCDF},{ }^{13} \mathrm{C}_{12}-1,2,3,7,8,9-\mathrm{HxCDF}$, and $\left.{ }^{13} \mathrm{C}_{12}-1,2,3,4,7,8,9-\mathrm{HpCDF}\right)$ before sampling.

\section{Sample preparation and analysis}

The stack gas samples were spiked with ${ }^{13} \mathrm{C}_{10}$-labeled PCN (ECN-5102, tetra-octa-CNs mixture comprising ${ }^{13} \mathrm{C}_{10^{-}}$ CN27, 42, 52, 67, 73, and 75; Cambridge Isotope Laboratories, USA) internal standards and were then Soxhlet extracted with toluene for approximately $24 \mathrm{~h}$. Subsequently, the sample extracts were concentrated and subjected to a series of cleanups by adsorption chromatography including an acid silica gel column, a multilayer silica gel column (from top to bottom: anhydrous sodium sulfate, $1 \mathrm{~g}$ activated silica gel, $8 \mathrm{~g}$ silica/ $\mathrm{H}_{2} \mathrm{SO}_{4} 44 \%(w / w)$ gel, $1 \mathrm{~g}$ activated silica gel, $5 \mathrm{~g}$ silica/ $\mathrm{NaOH}(1 \mathrm{M}) 33 \%(w / w)$ gel, $1 \mathrm{~g}$ activated silica gel, $2 \mathrm{~g}$ of silica/ $\mathrm{AgNO}_{3} 10 \%(w / w)$ gel, and $1 \mathrm{~g}$ activated silica gel) and a basic alumina column. Finally, the extracts were concentrated to approximately $20 \mu \mathrm{L}$ by rotary evaporation and a gentle stream of nitrogen gas. Prior to injection, a ${ }^{13} \mathrm{C}_{10}$-labeled $\mathrm{PCN}$ syringe standard (ECN-5260: ${ }^{13} \mathrm{C}_{10}$-CN64, Cambridge Isotope Laboratories, USA) was added to the extracts. PCNs were analyzed using a gas chromatograph (GC) coupled with a DFS mass spectrometer (MS; Thermo Fisher Scientific, USA) with electron impact ion source. The high resolution MS was operated in selected ion monitoring mode with a resolution greater than 10,000 . One microliter of the final concentrate of extract was injected with an autosampler in splitless mode. A DB-5 fused silica capillary column $(60 \mathrm{~m} \times 0.25 \mathrm{~mm}$ i.d. $\times$ $0.25 \mu \mathrm{m}$ ) was used for the separation of PCN congeners. The electron emission energy was set to $45 \mathrm{eV}$. The source temperature was $270^{\circ} \mathrm{C}$. The column temperature program was as follows: isothermal at $80{ }^{\circ} \mathrm{C}$ for $2 \mathrm{~min}, 20^{\circ} \mathrm{Cmin}^{-1}$ to $180{ }^{\circ} \mathrm{C}$, held at $180^{\circ} \mathrm{C}$ for $1 \mathrm{~min}, 2.5^{\circ} \mathrm{Cmin}^{-1}$ to $280^{\circ} \mathrm{C}$, 
Table 1 Detailed information of waste incinerators investigated

\begin{tabular}{|c|c|c|c|c|}
\hline Plant denotation & Incinerator type & Capacity (ton/day) & APCS & Type of waste material \\
\hline WI1 & Fluidized bed incinerator & 350 & $\mathrm{SDC}+\mathrm{AC}+\mathrm{BF}$ & Municipal solid waste \\
\hline WI2 & Fluidized bed incinerator & 480 & $\mathrm{SDC}+\mathrm{AC}+\mathrm{BF}$ & Municipal solid waste \\
\hline WI3 & Fluidized bed incinerator & 350 & $\mathrm{SDC}+\mathrm{AC}+\mathrm{BF}$ & Municipal solid waste \\
\hline WI4 & Grate incinerator & 100 & $\mathrm{SDC}+\mathrm{AC}+\mathrm{BF}$ & Municipal solid waste \\
\hline WI5 & Grate incinerator & 800 & $\mathrm{SDC}+\mathrm{AC}+\mathrm{DBF}$ & Municipal solid waste \\
\hline WI6 & Rotary kiln + SCC & 25 & $\mathrm{SDC}+\mathrm{AC}+\mathrm{BF}$ & Aviation waste \\
\hline WI7 & Rotary kiln + SCC & 15 & $\mathrm{SDC}+\mathrm{AC}+\mathrm{BF}+\mathrm{WS}$ & Medical waste \\
\hline WI8 & Rotary kiln + SCC & 20 & $\mathrm{SDC}+\mathrm{AC}+\mathrm{BF}$ & Hazardous waste \\
\hline WI9 & Cement kiln & 120 & $\mathrm{SDC}+\mathrm{BF}$ & Hazardous waste \\
\hline
\end{tabular}

$S C C$ secondary combustion chamber, $S D C$ semi-dry scrubber, $A C$ activated carbon, $B F$ bag filter, $D B F$ dual bag filter, $W S$ wet scrubber

$10^{\circ} \mathrm{Cmin}^{-1}$ to $290^{\circ} \mathrm{C}$, and finally held at $290^{\circ} \mathrm{C}$ for $5 \mathrm{~min}$. The carrier gas was helium with a flow rate of $1 \mathrm{mLmin}^{-1}$.

Quality control and assurance

Some native standards (CN13, 27, 42, 52, 54, 64, 67, 70, 73, and 75, Cambridge Isotope Laboratories, USA) and technical Halowax 1014 (Accustandard, USA) together with ${ }^{13} \mathrm{C}$-labeled standards $\left({ }^{13} \mathrm{C}_{10}\right.$-CN27, 42, 52, 64, 67, 73, and 75) were used to identify the elution pattern of PCN congeners. The peaks were identified based on retention time compared with available individual standards and ion ratios. The elution order of the PCN congeners on the DB-5 column was also taken into account (Schneider et al. 1998; Abad et al. 1999). Peaks were quantified if the GC retention times matched those of the standard compounds and the ratios of target/qualifier ion were within $15 \%$ of the theoretical values. The detection limits and quantification limits were defined as three and ten times the signal-to-noise ratio, respectively. The recoveries of sampling and internal labeled standards in the samples were in the range of 74-90 and 42$88 \%$, respectively (Electronic supplementary material (ESM) Table S2). Blank experiments were carried out in each batch of samples. Some mono- and di-chlorinated congeners were detected in the blank sample, but their concentrations were all lower than $5 \%$ that in the stack gas samples. The PCN concentrations in samples were not corrected with blank values in this study. The analysis procedure and quality control for $\mathrm{PCDD} / \mathrm{Fs}, \mathrm{PCBs}, \mathrm{PeCBz}$ and $\mathrm{HxCBz}$ can be found in the ESM.

\section{Statistical analysis}

To evaluate the relationships between the concentrations of PCNs and other U-POPs from the waste incinerators investigated, a principal component analysis (PCA) was applied. Correlation analysis (CA) was performed among closely related compounds to investigate their relationships further. PCA and CA were performed using SPSS 13.0 for Windows.

\section{Results and discussion}

Concentration of PCNs emitted from waste incinerators investigated

The concentration of PCNs in the stack gas samples from each waste incinerator is presented in Table 2. PCN
Table 2 PCN concentrations, chlorination degrees, and dl-PCN/PCN ratios in stack gas from investigated waste incinerators

${ }^{\text {a }}$ Calculated as $\Sigma[$ (homologue/ total PCNs) $\times$ no. of $\mathrm{Cl}]$

\begin{tabular}{llllll}
\hline Plant denotation & $\begin{array}{l}\text { Total PCNs } \\
\left(\mathrm{ngNm}^{-3}\right)\end{array}$ & $\begin{array}{l}\text { dl-PCNs } \\
\left(\mathrm{ngNm}^{-3}\right)\end{array}$ & $\begin{array}{l}\text { dl-PCN TEQs } \\
\left(\mathrm{pg} \mathrm{TEQNm}^{-3}\right)\end{array}$ & $\begin{array}{l}\text { dl-PCN/PCN } \\
\text { ratios }\end{array}$ & $\begin{array}{l}\text { Chlorination } \\
\text { degree }^{\mathrm{a}}\end{array}$ \\
\hline WI1 & 13000 & 11300 & 198 & 0.87 & 1.22 \\
WI2 & 239 & 211 & 6.43 & 0.88 & 1.38 \\
WI3 & 874 & 275 & 18.6 & 0.31 & 2.71 \\
WI4 & 786 & 90.3 & 32.9 & 0.11 & 3.34 \\
WI5 & 185 & 16.7 & 3.09 & 0.09 & 3.33 \\
WI6 & 330 & 29.1 & 2.16 & 0.09 & 3.17 \\
WI7 & 97.6 & 23.4 & 1.74 & 0.24 & 3.08 \\
WI8 & 379 & 47.3 & 1.76 & 0.12 & 2.92 \\
WI9 & 282 & 228 & 5.71 & 0.81 & 1.49 \\
\hline
\end{tabular}


Fig. 1 Homologue profiles of PCN in stack gas samples from investigated waste incinerators

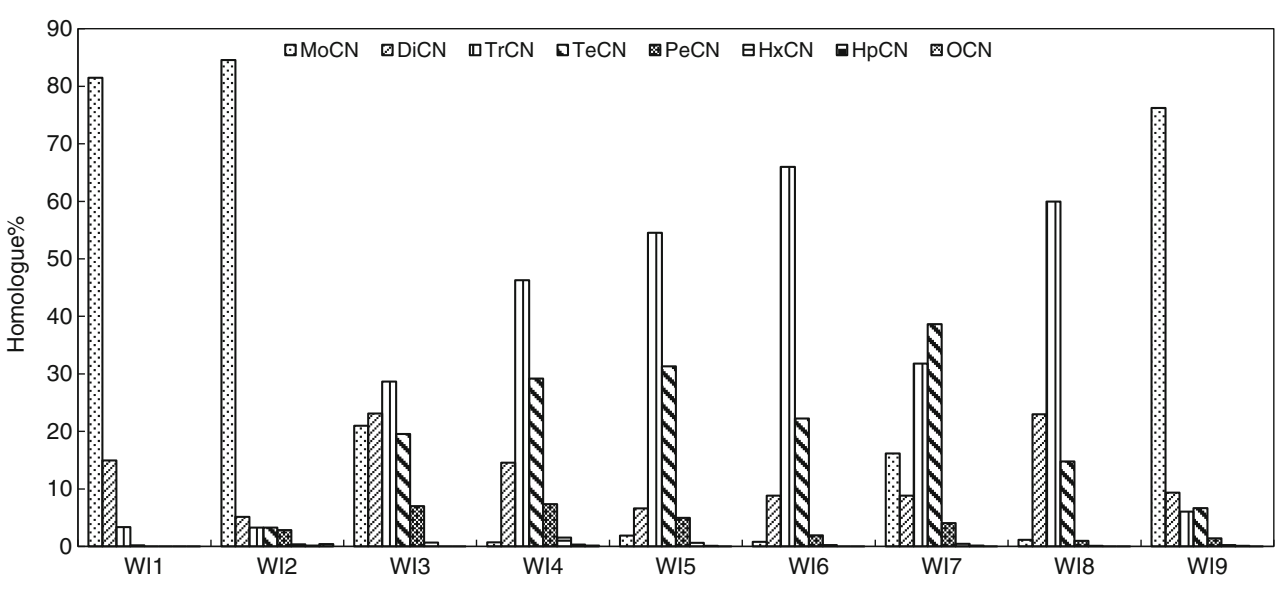

concentrations varied considerably among different waste incinerators. An unexpectedly high concentration of PCNs $\left(13,000 \mathrm{ng} \mathrm{Nm}^{-3}\right)$ was found in the stack gas emitted from WI1. The PCN concentrations ranged from 97.6 to $874 \mathrm{ng}$ $\mathrm{Nm}^{-3}$ in other waste incinerators. Some other studies have investigated PCN emissions from MSW incinerators. Abad et al. (1999) determined the PCN concentrations in stack gas samples from five MSW incinerators and found that the total PCN levels ranged from 1.08 to $21.4 \mathrm{ngNm}^{-3}$. Oh et al. (2007) reported that concentrations of PCNs in raw gas collected just before the APCS under various operating conditions were in the range of $939-9,990 \mathrm{ngm}^{-3}$ in a MSW incinerator. To our knowledge, emissions of PCNs from medical waste incinerators, hazardous waste incinerators, and cement kilns with hazardous waste disposal have, however, not been reported. The concentrations of PCNs emitted from waste incinerators in this study were higher than those of five MSW incinerators reported by Abad et al. (1999), but lower than that of raw gas from a MSW incinerator reported by $\mathrm{Oh}$ et al. (2007).

The dioxin-like toxicity of PCNs has been investigated in previous studies (Hanberg et al. 1990; Blankenship et al. 2000; Villeneuve et al. 2000). The relative potency factors (RPFs) of individual PCN congeners to 2378-TCDD estimated in these studies have been used to evaluate the toxicity of PCNs (Noma et al. 2004; Guo et al. 2008; Liu et al. 2009). In this study, the TEQs of PCNs were defined by the sum of the products of the concentration of each congener multiplied by its RPF reported by Noma et al. (ESM Table S1). The dioxin-like PCNs (dl-PCNs) were defined as those congeners whose toxic equivalent factors have been suggested (ESM Table S1). The concentrations of dl-PCNs ranged from 16.7 to $275 \mathrm{ngNm}^{-3}$ in WI2-WI9 while an unexpectedly high concentration of dl-PCNs (11,300 ng $\mathrm{Nm}^{-3}$ ) was found in the stack gas emitted from WI1 (Table 2). The TEQs of the dl-PCNs ranged from 1.74 to $198 \mathrm{pgTEQNm}^{-3}$, which were lower than that of PCDD/Fs, but comparable with that of PCBs in the waste incinerators investigated (ESM Table S3).
Profiles of emitted PCNs

The homologue profiles of PCNs emitted from the waste incinerators are shown in Fig. 1. In WI1, WI2 and WI9, mono-CNs were the predominant homologue and their contributions to total PCNs (mono- to octa-CNs) were 81.5, 84.5 , and $76.2 \%$, respectively. The weight distribution of homologues decreased with increasing degree of chlorination in these three plants. In the other waste incinerators, di-, tri-, and tetra-CNs were the predominant homologues. PCN homologue profiles were dominated by lower chlorinated homologues (mono- to tetra-CNs) in each waste incinerator investigated. The degree of chlorination of PCNs was in the range of 1.22-3.34 (Table 2), which is comparable with that of coking industries (Liu et al. 2010). WI1, WI2, and WI9 emitted PCNs with relatively lower degree of chlorination (1.22-1.49) compared with emissions from the other incinerators (2.71-3.34). On the other hand, emissions from WI1, WI2, and WI9 were characterized with relatively greater contents of dl-like PCNs. These three plants had dl-PCNs/ total PCNs ratios ranging from 0.8 to 0.88 , compared with

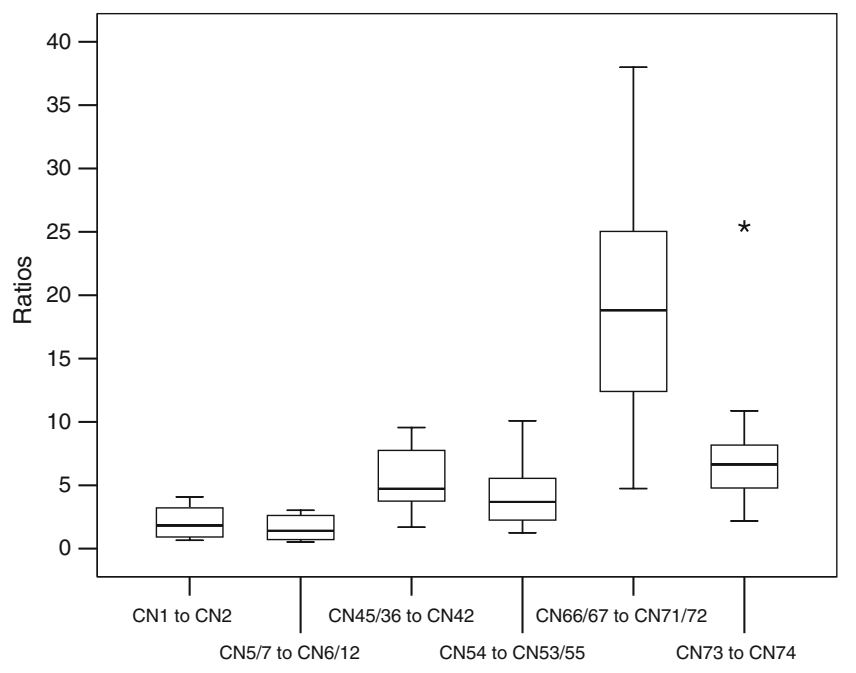

Fig. 2 Ratios of some characteristic PCN congeners 
Fig. 3 TEQ congener profiles of dl-PCN in stack gas samples from investigated waste incinerator

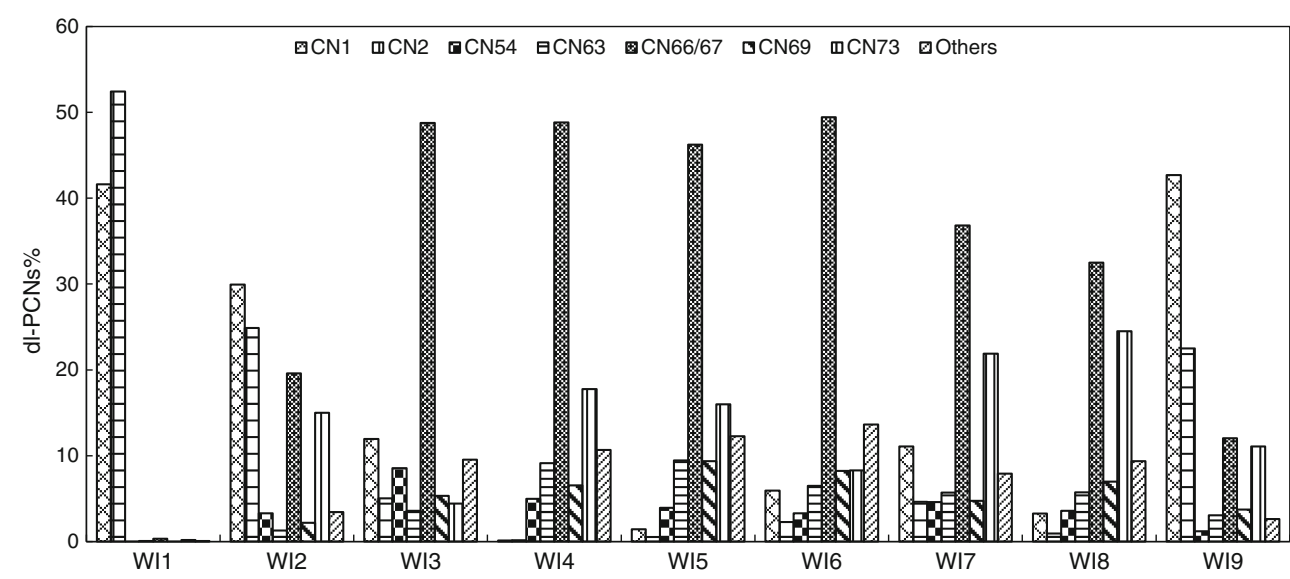

$0.09-0.31$ for the remaining plants. It is possible that the difference in type of incinerators as well as the type of waste incinerated may be responsible for the difference in the degree of chlorination and dl-PCN/total PCN ratios. For instance, it has been suggested that different PCN emission patterns may exist between fluidized bed and some grate MSW incinerators (Iino et al. 2001; Weber et al. 2001).

The characteristics of PCN profiles from different cataloged sources have been applied to identify the specific source of PCNs in the environment (Schneider et al. 1998; Helm and Bidleman 2003; Pan et al. 2011). The major sources of PCNs in the environment were the technical formulations of PCNs (such as the Halowax series), industrial thermal processes, and impurities in technical formulations of PCBs (Abad et al. 1999; Yamashita et al. 2000; Ba et al. 2010; Liu et al. 2010). Some PCN congeners have been identified that are absent or present in trace amounts in the technical formulations of PCNs and PCBs but are abundant in thermal-related processes (Schneider et al. 1998; Helm and Bidleman 2003; Helm et al. 2004). These congeners were recognized as combustion-related congeners and have been used to analyze the sources of PCNs in air (Helm and Bidleman 2003; Helm et al. 2004). On the other hand, the ratios of selected PCN congeners may also indicate a possible source. For instance, the ratios of $\mathrm{CN} 1$ to $\mathrm{CN} 2$ and $\mathrm{CN} 5 / 7$ to $\mathrm{CN} 6 / 12$ were distinctly different between fly ash samples from MSW incinerators and
Halowax samples (Schneider et al. 1998). Similarly, the ratio of $\mathrm{CN} 73$ to $\mathrm{CN} 74$ varies in samples from different sources with the values being less than 1 for Halowaxes, but greater than 1 in stack gas or fly ash samples from thermal-related sources (Abad et al. 1999; Noma et al. 2004; Takasuga et al. 2004; Liu et al. 2012). In this study, the ratios of some characteristic PCN congeners were also determined and are shown in Fig. 2. These ratios are obviously different from those of the technical formulations of PCNs and impurities of PCNs in technical formulations of PCBs (ESM Fig. S2; Falandysz et al. 2000; Yamashita et al. 2000; Noma et al. 2004; Falandysz et al. 2006a, b). This may provide useful information for identifying specific PCN sources.

With regard to the toxic profiles of PCNs from waste incinerators, the TEQ contributions of PCN congeners, for which RPFs have been suggested, are shown in Fig. 3. CN1 and $\mathrm{CN} 2$ were the dominant toxic congeners owing to their high concentrations in WI1, WI2, and WI9. In other incinerators, the most dominant toxic congeners were CN66/77 and CN73 owing to their relatively high RPFs compared with other PCN congeners. The toxic profiles of PCNs in this study were similar to that of the coking industries and secondary nonferrous metallurgical facilities (Liu et al. 2009; Ba et al. 2010). In these studies, CN1, CN2, CN66/ 77 , and CN73 were also the main toxic contributors.

A significant positive correlation was observed between adjacent PCN homologues, but mono-CNs and di-CNs
Table 3 Pearson coefficient between each PCN homologue

${ }^{\mathrm{a} C}$ Correlation is significant at 0.01 level (two tailed)

${ }^{\mathrm{b}}$ Correlation is significant at 0.05 level (two tailed)

\begin{tabular}{lllllllll}
\hline PCN & MoCN & DiCN & TrCN & TeCN & PeCN & HxCN & HpCN & OCN \\
\hline MoCN & 1 & & & & & & & \\
DiCN & $0.995^{\mathrm{a}}$ & 1 & & & & & & \\
TrCN & 0.604 & $0.669^{\mathrm{b}}$ & 1 & & & & & \\
$\mathrm{TeCN}$ & -0.255 & -0.171 & 0.523 & 1 & & & & \\
$\mathrm{PeCN}$ & -0.218 & -0.133 & 0.417 & $0.937^{\mathrm{a}}$ & 1 & & & \\
$\mathrm{HxCN}$ & -0.197 & -0.128 & 0.466 & $0.944^{\mathrm{a}}$ & $0.906^{\mathrm{a}}$ & 1 & & \\
$\mathrm{HpCN}$ & -0.168 & -0.128 & 0.379 & $0.773^{\mathrm{b}}$ & $0.675^{\mathrm{b}}$ & $0.921^{\mathrm{a}}$ & 1 & \\
OCN & -0.070 & -0.060 & 0.114 & 0.332 & 0.394 & 0.566 & $0.691^{\mathrm{b}}$ & 1 \\
\hline
\end{tabular}




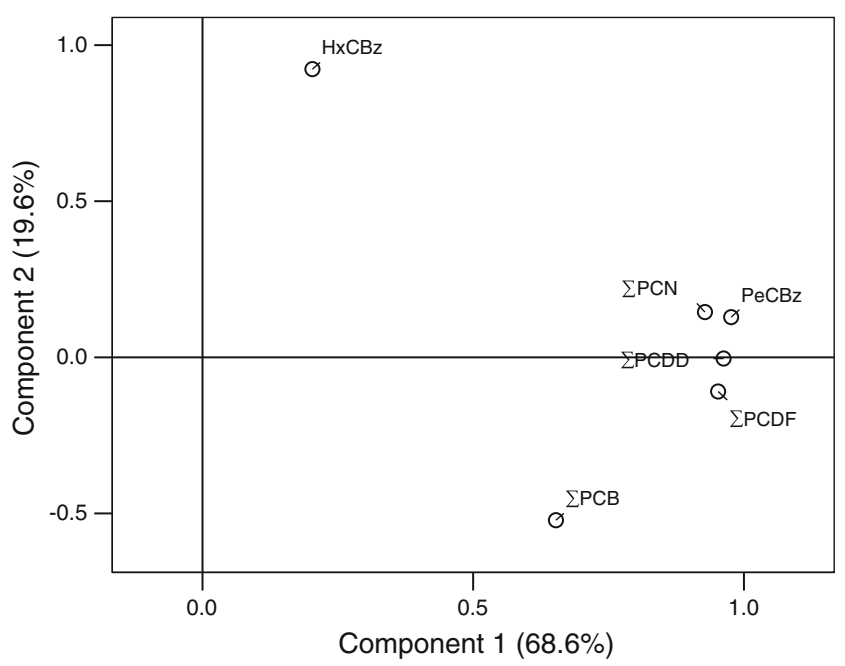

Fig. 4 Component plot of PCA base on concentrations of target compounds

showed a negative correlation with the tetra- through octaCNs (Table 3). Furthermore, the Pearson correlation coefficient decreased with increasing chlorine substitution among tri- through octa-CNs. For example, the Pearson coefficient between tri-CNs and tetra-CNs was 0.523 but decreased to 0.417 between tri-CNs and penta-CNs, and to 0.379 between tri-CNs and hepta-CNs. These results suggest that chlorination may occur in a stepwise manner during the formation of PCNs in waste incinerators, such that most of the tri-CNs for instance, may form before the tetra-CNs, penta-CNs until the octa-CNs in that order (Oh et al. 2007).

\section{Relationships among PCNs and other U-POPs}

We presume that it is possible to extend some of the existing approaches at controlling classical U-POPs (such as PCDD/ Fs, PCBs, and chlorobenzenes) from incinerators to also control emissions of PCNs. Such a judgment would depend on our understanding of the relationships between emissions of the PCNs and classical U-POPs during incineration. The concentrations of PCDD/Fs (tetra- to octa-CDD/Fs, noted as $\Sigma \mathrm{PCDD} / \mathrm{Fs}$ ), PCBs (tetra- to deca-CBs, noted as $\Sigma \mathrm{PCBs}$ ), $\mathrm{HxCBz}$, and $\mathrm{PeCBz}$ were also determined in the stack gas from the various incinerators (ESM Table S3). The relationships between $\mathrm{EPCNs}$ (tetra- to octa-CNs) and the other UPOPs were investigated by PCA (Fig. 4). In the PCA, the different incinerators were treated as cases and the concentrations of various compounds constituted the variables. $\Sigma P C N$ s concentrations were closely related to $\Sigma P C D F s$, $\Sigma$ PCDDs, and $\mathrm{PeCBz}$ concentrations, more so than to that of $\Sigma$ PCBs and HxCBz. Further analysis by scatter plot showed that the $\Sigma \mathrm{PCN}$ generally correlated well with ¿PCDDs $\left(r^{2}=0.46\right)$, $\Sigma$ PCDFs $\left(r^{2}=0.73\right)$, and PeCBz $\left(r^{2}=0.65\right.$; ESM Fig. S1). Given the strongest correlation coefficient between $\Sigma$ PCNs and $\Sigma$ PCDFs, the formation mechanisms of these two compounds may be closely related, a result which is consistent with previous findings (Imagawa and Lee 2001; Oh et al. 2007). Therefore, the technologies applied in reducing dioxin emissions from waste incinerators may be also effective for the control of PCN emissions.

\section{Conclusion}

The release levels and characteristics of PCNs were investigated in nine different waste incinerators. Lower chlorinated PCNs were the main homologues in the stack gas emitted from these waste incinerators. It was speculated that chlorination is possibly a main pathway of $\mathrm{PCNs}$ formation in investigated waste incinerators. Furthermore, other U-POPs were determined and their relationships with PCNs were examined. It was suggested that a close relationship may exist between the formation mechanism of PCNs and PCDFs. These results are helpful to understand PCN emissions from waste incinerators; but most importantly, they suggest that existing technology used in controlling classical U-POPs could also be applied to control PCN emissions.

Acknowledgments Financial support for the present work was obtained from the National 973 Program (nos. 2011CB201500 and 2009CB421606), Knowledge Innovation Program of the Chinese Academy of Sciences (KZCX2-YW-JS406) and National Natural Science Foundation of China (no. 21037003).

\section{References}

Abad E, Caixach J, Rivera J (1999) Dioxin like compounds from municipal waste incinerator emissions: assessment of the presence of polychlorinated naphthalenes. Chemosphere 38:109-120

Ba T, Zheng M, Zhang B, Liu W, Su G, Liu G, Xiao K (2010) Estimation and congener-specific characterization of polychlorinated naphthalene emissions from secondary nonferrous metallurgical facilities in China. Environ Sci Technol 44:2441-2446

Behnisch PA, Hosoe K, Shiozaki K, Kiryu T, Komatsu K, Schramm KW, Sakai S (2002) Melting and incineration plants of municipal waste-chemical and biochemical diagnosis of thermal processing samples (emission, residues). Environ Sci Pollut Res 9:337-344

Bidleman TF, Helm PA, Braune BM, Gabrielsen GW (2010) Polychlorinated naphthalenes in polar environments - a review. Sci Total Environ 408:2919-2935

Blankenship AL, Kannan K, Villalobos SA, Villeneuve DL, Falandysz J, Imagawa T, Jakobsson E, Giesy JP (2000) Relative potencies of individual polychlorinated naphthalenes and halowax mixtures to induce $\mathrm{Ah}$ receptor-mediated responses. Environ Sci Technol 34:3153-3158

Domingo JL (2004) Polychlorinated naphthalenes in animal aquatic species and human exposure through the diet: a review. J Chromatogr A 1054:327-334 
Falandysz J (1998) Polychlorinated naphthalenes: an environmental update. Environ Pollut 101:77-90

Falandysz J, Kawano M, Ueda M, Matsuda M, Kannan K, Giesy JP, Wakimoto T (2000) Composition of chloronaphthalene congeners in technical chloronaphthalene formulations of the Halowax series. J Environ Sci Health, Part A: Tox Hazard Subst Environ Eng 35:281-298

Falandysz J, Nose K, Ishikawa Y, Lukaszewicz E, Yamashita N, Noma Y (2006a) HRGC/HRMS analysis of chloronaphthalenes in several batches of Halowax 1000, 1001, 1013, 1014 and 1099. J Environ Sci Health, Part A: Tox Hazard Subst Environ Eng 41:2237-2255

Falandysz J, Nose K, Ishikawa Y, Lukaszewicz E, Yamashita N, Noma Y (2006b) Chloronaphthalenes composition of several batches of Halowax 1051. J Environ Sci Health, Part A: Tox Hazard Subst Environ Eng 41:291-301

Guo L, Zhang B, Xiao K, Zhang Q, Zheng M (2008) Levels and distributions of polychlorinated naphthalenes in sewage sludge of urban wastewater treatment plants. Chin Sci Bull 53:508-513

Hanberg A, Waern F, Asplund L, Haglund E, Safe S (1990) Swedish dioxin survey: determination of 2,3,7,8-TCDD toxic equivalent factors for some polychlorinated-biphenyls and naphthalenes using biological tests. Chemosphere 20:1161-1164

Helm PA, Bidleman TF (2003) Current combustion-related sources contribute to polychlorinated naphthalene and dioxin-like polychlorinated biphenyl levels and profiles in air in Toronto, Canada. Environ Sci Technol 37:1075-1082

Helm PA, Bidleman TF, Li HH, Fellin P (2004) Seasonal and spatial variation of polychlorinated naphthalenes and Non-/Mono-Orthosubstituted polychlorinated biphenyls in arctic Air. Environ Sci Technol 38:5514-5521

Iino F, Tsuchiya K, Imagawa T, Gullett BK (2001) An isomer prediction model for PCNs, PCDD/Fs, and PCBs from municipal waste incinerators. Environ Sci Technol 35:3175-3181

Imagawa T, Lee CW (2001) Correlation of polychlorinated naphthalenes with polychlorinated dibenzofurans formed from waste incineration. Chemosphere 44:1511-1520

Jansson S, Fick J, Marklund S (2008) Formation and chlorination of polychlorinated naphthalenes (PCNs) in the post-combustion zone during MSW combustion. Chemosphere 72:1138-1144

Jansson S, Antti H, Marklund S, Tysklind M (2009) Multivariate relationships between molecular descriptors and isomer distribution patterns of PCDD/Fs formed during MSW combustion. Environ Sci Technol 43:7032-7038

Liu G, Zheng M, Liu W, Wang C, Zhang B, Gao L, Su G, Xiao K, Lv P (2009) Atmospheric emission of PCDD/Fs, PCBs, hexachlorobenzene, and pentachlorobenzene from the coking industry. Environ Sci Technol 43:9196-9201

Liu G, Zheng M, Lv P, Liu W, Wang C, Zhang B, Xiao K (2010) Estimation and characterization of polychlorinated naphthalene emission from coking industries. Environ Sci Technol 44:8156-8161

Liu G, Zheng M, Du B, Nie Z, Zhang B, Liu W, Li C, Hu J (2012) Atmospheric emission of polychlorinated naphthalenes from iron ore sintering processes. Chemosphere 89:467-472
Marti-Cid R, Llobet JM, Castell V, Domingo JL (2008) Human exposure to polychlorinated naphthalenes and polychlorinated diphenyl ethers from foods in Catalonia, Spain: temporal trend. Environ Sci Technol 42:4195-4201

Ni Y, Zhang H, Fan S, Zhang X, Zhang Q, Chen J (2009) Emissions of $\mathrm{PCDD} / \mathrm{Fs}$ from municipal solid waste incinerators in China. Chemosphere 75:1153-1158

Noma Y, Yamamoto T, Sakai SI (2004) Congener-specific composition of polychlorinated naphthalenes, coplanar PCBs, dibenzo- $p$ dioxins, and dibenzofurans in the halowax series. Environ Sci Technol 38:1675-1680

Oh J-E, Gullett B, Ryan S, Touati A (2007) Mechanistic relationships among PCDDs/Fs, PCNs, PAHs, CIPhs, and CIBzs in municipal waste incineration. Environ Sci Technol 41:4705-4710

Olivero-Verbel J, Vivas-Reyes R, Pacheco-Londoño L, JohnsonRestrepo B, Kannan K (2004) Discriminant analysis for activation of the aryl hydrocarbon receptor by polychlorinated naphthalenes. J Mol Struct (THEOCHEM) 678:157-161

Pan X, Tang J, Chen Y, Li J, Zhang G (2011) Polychlorinated naphthalenes (PCNs) in riverine and marine sediments of the Laizhou Bay area, North China. Environ Pollut 159:3515-3521

Park H, Kang J-H, Baek S-Y, Chang Y-S (2010) Relative importance of polychlorinated naphthalenes compared to dioxins, and polychlorinated biphenyls in human serum from Korea: contribution to TEQs and potential sources. Environ Pollut 158:1420-1427

Schneider M, Stieglitz L, Will R, Zwick G (1998) Formation of polychlorinated naphthalenes on fly ash. Chemosphere 37:2055-2070

Shin SK, Kim KS, You JC, Song BJ, Kim JG (2006) Concentration and congener patterns of polychlorinated biphenyls in industrial and municipal waste incinerator flue gas, Korea. J Hazard Mater 133:53-59

Takasuga T, Inoue T, Ohi E, Kumar KS (2004) Formation of polychlorinated naphthalenes, dibenzo- $p$-dioxins, dibenzofurans, biphenyls, and organochlorine pesticides in thermal processes and their occurrence in ambient air. Arch Environ Contam Toxicol 46:419-431

Villeneuve DL, Kannan K, Khim JS, Falandysz J, Nikiforov VA, Blankenship AL, Giesy JP (2000) Relative potencies of individual polychlorinated naphthalenes to induce dioxin-like responses in fish and mammalian in vitro bioassays. Arch Environ Contam Toxicol 39:273-281

Weber R, Iino F, Imagawa T, Takeuchi M, Sakurai T, Sadakata M (2001) Formation of PCDF, PCDD, PCB, and PCN in de novo synthesis from $\mathrm{PAH}$ : mechanistic aspects and correlation to fluidized bed incinerators. Chemosphere 44:1429-1438

Wegiel M, Chrzaszzcz R, Maślanka A, Grochowalski A (2011) Study on the determination of PCDDs/Fs and $\mathrm{HCB}$ in exhaust gas. Chemosphere 85:481-486

Yamashita N, Kannan K, Imagawa T, Miyazaki A, Giesy JP (2000) Concentrations and profiles of polychlorinated naphthalene congeners in eighteen technical polychlorinated biphenyl preparations. Environ Sci Technol 34:4236-4241

Yan M, Li XD, Lu SY, Chen T, Chi Y, Yan JH (2011) Persistent organic pollutant emissions from medical waste incinerators in China. J Mater Cy Waste Manag 13:213-218 